\title{
Uudet riskienhallinnan välineet maatilan johtamisessa
}

\author{
Jarkko Leppälä $^{1)}$, Mervi Murtonen ${ }^{2)}$, Juha Suutarinen ${ }^{3)}$ \\ 1) MTT taloustutkimus, Vakolantie 55, 03400 Vihti, etunimi.sukunimi@mtt.fi \\ 2) VTT , Tekniikankatu 1, 33100 Tampere, etunimi.sukunimi@vtt.fi \\ 3) MTT taloustutkimus , Luutnantintie 13,00410 Helsinki, etunimi.sukunimi@mtt.fi
}

Maatalousalalla varmaa nykyisin on vain muutos. Maatilojen määrä Suomessa on vähentynyt 330 000:sta maatilasta 70 000:en maatilaan kolmenkymmenen vuoden aikana, mitä voidaan pitää varsin nopeana rakennekehityksen tahtina. Maatiloilla muutokset johtuvat usein politiikan, markkinoiden ja tuotantoteknologian muutoksista. Nykyaikaisen maatilan johtaminen kokonaisuutena edellyttää viljelijältä realistista ja reaaliaikaista kuvaa maatilan resursseista, osaamisesta, tilan toimintaan liittyvistä vaatimuksista ja tuotanto- ja työprosesseista. Toiminnan kehittäminen edellyttää tavoitteiden asettamista, seurantaa ja tulosten arviointia. Ongelmana on, että maatilojen on yhä vaikeampaa hallita tilan toimintoja muuttuvien toimintaolosuhteiden ja vaatimusten kasvaessa. Maatilan johtamisessa ja toiminnan muutosten hallinnassa maatilayrittäjä voi käyttää apuna erilaisia johtamisen välineitä kuten laatujärjestelmän ja kokonaisvaltaisen riskienhallinnan välineitä.

MTT: n ja VTT:n johtamassa Maatilojen turvallisuusjohtamisen (Maaturva) yhteishankkeessa on kehitetty ja testattu erityyppisiä maatilan turvallisuusjohtamisen ja riskien hallinnan välineitä. Hankkeessa kehitettyjä välineitä ovat maatilan riskien tarkistuslistat, prosessien ja resurssien johtamisen suunnittelutyökalut, riskikarttatyökalu sekä vuosikello ajanhallintaan ja yhteenvedon laatimiseen. Välineiden soveltamista varten on tehty käyttöohje. Uudet riskienhallinnan välineet on tarkoitettu maatilan johtamisen tueksi ja niiden avulla tilalla voidaan vähentää tuotantoprosessien häiriöitä ja parantaa tuotanto-olosuhteita. Maatilan riskien hallinta voi toimia myös osana laadun hallintaa, sillä se osaltaan ohjaa järjestelmälliseen ja hallittuun maatilan hallintaan ja kehittämiseen. Riskin suuruutta arvioidaan määritellyn haitallisen tapahtuman todennäköisyyden ja seurauksen merkityksen tai vakavuuden perusteella. Maatilan turvallisuusriskeillä tarkoitamme kaikkia haitallisia ei- toivottuja tapahtumia tai ilmiöitä, jotka voivat vaarantaa maatilan liiketoiminnan ja tuotannon jatkuvuuden, ihmisten ja eläinten hyvinvoinnin, omaisuuden arvon ja ympäristön laadun. Riskien hallinnan avulla voidaan löytää myös uusia keinoja ja menetelmiä ratkaista työympäristön tai tuotantoprosessien ongelmia.

Maatilan johtamisessa riskien tunnistamista ja hallintaa voidaan käyttää hyväksi muutoksen hallinnassa, toiminnan suunnittelussa, työtehtävien tärkeysjärjestyksen laatimisessa ja päätöksenteossa. Riskien tarkastelun avulla voidaan toisaalta myös tunnistaa osa-alueita, joissa riskit ovat vähäiset. Nämä nousevat silloin esiin selkeinä mahdollisuuksina tai vahvuuksina toiminnassa. Lähtökohtana on, että jos jonkin asian tietää ja osaa hyvin sekä pystyy tarkistamaan resurssien toimivuuden, niin asioissa on pienempi riski epäonnistua. Päätöksenteossa kokonaisvaltaista riskien hallintaa voidaan myös käyttää yhdistämään muutoin vaikeasti yhdistettäviä arvovalintoja.

Riskien tarkastelu tuo esiin toiminnassa olevia heikkouksia mutta samalla myös mahdollisuuksia. Kun riskejä tarkastellaan systemaattisesti osana maatilan toimintaa ja suunnittelua, saadaan esiin selkeitä toimintaohjelmia ja tietoja, joita tarvitaan maatilan johtamisessa. Tällöin vähennetään epävarmuutta toiminnassa, mahdollisia häiriöitä ja omaa maatilaa uhkaavia heikkouksia. Tuloksena on maatila, jolla on vakaa toimintaohjelma, mutta joka tarpeen tullen pystyy nopeasti muuttamaan toimintaansa hallitusti. Maatila-RH riskienhallintavälineet on tarkoitus julkaista Agronetissä tammikuussa 2008. 


\begin{abstract}
Johdanto
Maatiloilla turvallisuuden kokonaishallinnan tarve pohjautuu mm. toimeentulon ja tukijärjestelmän epävarmuustekijöihin, maatalous- ja elintarvikemarkkinoiden muutoksiin, tuotantotöiden moninaisiin vaatimuksiin, maatalousyritysten suureen pääomavaltaisuuteen ja työvoimaresurssien vähäisyyteen (Rikkonen 2005; Jokipii ym. 2005; Sonkkila 2002). Turvallisuuden merkitys koko yrityksen toiminnassa kasvaa, kun toiminnan häiriöiden määrä kasvaa, vahinkojen merkittävyys kasvaa tai yleensä ottaen toiminnan epävarmuus kasvaa (Simola 2005, Reason 1995). Lisäksi Suutarisen (2003) tutkimuksessa todettiin, että johtamisen laatu vaikuttaa maatilan töiden toteutuksen turvallisuuteen ja riskeihin.

Vuosina 2005-2007 toteutettu Maaturva -hanke jakautui tutkimus- ja koulutusosioon. Tutkimusosion päätoteuttajia olivat Maa - ja elintarviketalouden tutkimuskeskus (MTT) ja Valtion teknillinen tutkimuskeskus (VTT). Keskinäinen vakuutusyhtiö Tapiola osallistui myös tutkimusryhmätyöhön. Hankkeen yleisenä tavoitteena oli parantaa maatilan johtamisen edellytyksiä turvallisuutta parantavien välineiden avulla. Tätä kehittämistyötä varten maatilojen turvallisuuden nykytilanne kartoitettiin kyselyllä, jäsennettiin maatilan turvallisuuden osa-alueet mielekkääksi kokonaisuudeksi, kehitettiin uusia riskien hallinnan välineitä ja testattiin kehitettyjä välineitä ohjelmaan osallistuneilla maatiloilla. Välineiden on oltava helppokäyttöisiä, ymmärrettäviä ja ne julkaistaan Agronet- viljelijäporttaalissa.
\end{abstract}

\title{
Riskienhallinnan käytännöt ovat osa hyvää turvallisuusjohtamista
}

Turvallisuusjohtamisella tarkoitetaan suunnitelmallista ja jatkuvaa prosessia, joka tähtää yrityksen toimintaan vaikuttavien riskien ja heikkouksien tunnistamiseen sekä toiminnalle vahingollisten tapahtumien ennaltaehkäisyyn (Lanne, 2007). Turvallisuusjohtamisen tavoitteena on ihmisiin, ympäristöön ja omaisuuteen kohdistuvien vahinkojen vähentäminen. Yrityksen kannalta turvallisuusjohtaminen on yrityksen liiketoimintaa ja tavoitteita tukeva prosessi, joka koostuu riskien arvioinneista ja analyyseistä, työmenetelmien kehittämisestä, teknisistä turvallisuusratkaisuista, työyhteisön ja ihmisten osaamisen kehittämisestä sekä seurannasta (Simola 2005; SFS OHSAS 2000).

Edellä kuvattu pätee myös maatilalla. Maatilan toiminta voi päättyä, jos tilan avainhenkilö sairastuu tai kuolee tai jos toiminnan resurssit ehtyvät tai pilaantuvat. Nämä ovat merkittäviä maatilaa koskevia riskejä. Lisäksi yrityksissä jatkuvuus on uhattuna myös silloin, jos toiminta on ollut lain- tai sopimusten vastaista. Tämä liittyy yleensä kannattavuuteen ja toiminnan riskeihin.

Riskienhallinta on johtamisperiaatteiden, menettelytapojen ja käytäntöjen järjestelmällistä hyväksi käyttämistä riskien analysoimiseksi, riskien merkityksen arvioimiseksi ja riskien valvomiseksi. (SFS-IEC 60300-3-9, 2000). Riskienhallinnan määrittely on kontekstiriippuvaista, mutta yritysten kokonaisvaltaisessa riskienhallinnassa on kyse yrityksen liiketoimintaan ja resursseihin vaikuttavien riskien tunnistamisesta, arvioinnista ja hallinnasta (COSO, 2004). Riskienhallinnan perusajatuksena on, että voidaan tunnistaa kriittisimmät turvallisuuden kehittämiskohteet ja käyttää kehittämisresurssit tehokkaasti.

Vaarojen tunnistaminen ja vaarojen aiheuttamien riskien arviointi muodostavat turvallisuusjohtamisen perustan. Perinteisesti riskien arvioinnin painopiste on ollut teknisten järjestelmien luotettavuuden ja turvallisuuden varmistamisessa. Vasta viime vuosikymmenen aikana on alettu kiinnittää enemmän huomiota organisaation toimintatapoihin (Levä, 2003). Teknisten vaaratekijöiden lisäksi huomion kohteena ovat myös muut haitalliset ei-toivotut tapahtumat ja ilmiöt, jotka voivat vaarantaa maatilan liiketoiminnan ja tuotannon jatkuvuuden, ihmisten ja eläinten hyvinvoinnin, omaisuuden arvon tai ympäristön laadun. Yritysten riskienhallintaan on olemassa paljon käytännönläheisiä ja yritysten omaan käyttöön soveltuvia työvälineitä. Pienten ja keskisuurten yritysten kokonaisvaltaisen riskienhallinnan kehittämiseen on VTT kehittänyt PK-RH riskienhallintavälineistön (www.pk-rh.com). Lisäksi kaikilla suurimmilla vakuutusyhtiöillä on omia menetelmiään yritysten laaja-alaisiin riskikartoituksiin. Laaja-alaisten riskikartoitusten lisäksi on paljon erilaisia välineitä yksittäisten riskilajien tarkempaan analysointiin esimerkiksi Työterveyslaitoksen menetelmäpakissa (www.ttl.fi/menetelmapakki). Palo- ja pelastustoimenalaan kuuluvia tarkistuslistavälineet on testattu Etelä-Pohjanmaan pelastuslaitoksen Maatilojen turvallisuushankkeessa (Karhu, 2005). Muita vaarojen tunnistamiseen ja riskien arviointiin liittyviä välineitä ovat yleiskäytössä olevat riskianalyysimenetelmät kuten vikapuuanalyysit, syy- ja seurausanalyysit ja tapaturmien syytekijä- analyysi. Näitä on esitelty VTT:n kokoamalla Riskianalyysit -sivustolla (www.vtt.fi/proj/riskianalyysit). Maatalouden laaturiskien arvioinnin kannalta merkittäviä 
välineitä ovat poikkeamatyökalut kuten vaaranpaikkojen analysointi, HACCP (Jokipii ym. 2005) ja nyt Maaturva-hankkeessa suunnitellut tuotannon riskityökalut.

Perinteisesti riskienhallinta etenee siten, että riskit tunnistetaan, arvioidaan, mietitään toimenpiteet riskien vähentämiseksi, toteutetaan toimenpiteet ja seurataan toimenpiteiden toimivuutta riskien vähentämiseksi. Riskien arviointia varten käytössä on yksinkertainen todennäköisyysvakavuus- taulukko (taulukko 1). Yleisesti voidaan sanoa laadun ja turvallisuuden olevan hyvin riippuvaisia tosistaan, sikäli että laatujohtamisen kaikkien kriteerien saavuttamiseksi toiminnan ja tuotannon on oltava myös turvallista ollakseen laadukasta ja päinvastoin. (Simola 2005).

Taulukko 1. Riskien arviointitaulukko (BS 8800).

\begin{tabular}{|l|l|l|l|}
\hline $\begin{array}{l}\text { Riskin } \\
\text { todennäköisyys }\end{array}$ & \multicolumn{2}{|l|}{ Riskin merkittävyys } \\
\hline & Vähäinen & Haitallinen & Vakava \\
\hline Epätodennäköistä & $\begin{array}{l}\text { 1. Merkityksetön } \\
\text { riski }\end{array}$ & 2. Vähäinen riski & 3. Kohtalainen riski \\
\hline Mahdollista & 2. vähäinen riski & 3. Kohtalainen riski & 4. Merkittävä riski \\
\hline Todennäköistä & 3. Kohtalainen riski & 4. Merkittävä riski & 5. Sietämätön riski \\
\hline
\end{tabular}

\section{Aineisto ja menetelmät}

Maatiloille suunniteltavien riskienhallinnan työvälineiden tarkoituksena on tukea maatiloja kehittämään omaa toimintaansa ja auttaa suunnittelemaan käytännön toimenpiteitä riskien pienentämiseksi. Turvallisuuden ja laadun parantamisen suhteen jokaisen maatilan johtamisjärjestelmä on omanlaisensa toimintamalli, joka on syntynyt kunkin maatilan monipuolisista resursseista, olosuhteista ja tavoitteista. Yritysten ja tässä tapauksessa maatilan riskien hallintaa, organisointia, kokonaisvaltaista kehittämistä sekä toiminnan vaihtoehtojen suunnittelua on mahdollista syventää esimerkiksi tavoitelähtöisesti, tietyin teemoin tai vakiokysymyksin kytkien ne tilakohtaiseksi räätälöinniksi (Carnaghan 2006; Jokipii ym.2005;Hardaker ym. 2004; Boehlje 1999).

Tässä tutkimuksessa välineiden kehittäminen perustui konstruktiiviseen ja systeemiteoreettiseen mallinnukseen. Konstruktiivisessa tutkimusotteessa oleellista on löytää uusi toimiva ratkaisu tai malli toimijoiden joukossa vallitsevaan ongelmaan. Kehittämistyön apuna käytettiin vuorovaikutteisten järjestelmien käytön suunnitteluprosessin standardia (SFS - EN ISO 13407 1999). Tavoiteltavaksi ongelmaksi tutkimuksessa asetettiin, millainen on maatiloille sopiva riskienhallintaväline ja miten sitä käytetään. Maatilojen riskienhallintavälineen taustamalleiksi asetettiin VTT:n suunnittelemat PK-RH - riskienhallintavälineistö, koska se oli kattava ja suunniteltu valmiiksi huomioimaan pienten - ja keskisuurten yritysten tarpeita. Lisäksi PK-RH:ssa oli valmiina hyväksi muilla toimialoilla koettuja välineitä. Tällöin täytyy vain selvittää, mitkä ovat maatilojen vaatimukset riskienhallinnan välineille ja rakentaa välineitä sen mukaan. Tarkoituksena oli myös, että maatilan turvallisuusasioiden hallintaa voisi soveltaa maatilan laatujohtamisessa.

Maatilojen johtamiseen liitettyjä vaatimuksia lähestyttiin kysymällä, mistä asioista maatilan johtaminen koostuu ja mitkä ovat tärkeimmät näitä osa-alueita uhkaavat riskit? Tämän lisäksi ongelmaksi muodostui maatilan toiminnan mahdollinen dynaamisuus ja tuotantoprosessien erilaisuus. Maatilojen vaatimusten mukaista oli, että riskienhallinnan välineiden tuli pystyä tarjoamaan vastauksia ja hyötyjä maatilan johtamisessa. Sen lisäksi välineille asetettavia muita kriteerejä olivat helppokäyttöisyys, ymmärrettävyys ja hyödyllisyys maatilan johtamisessa. Välineiden käyttö ei saa olla kuitenkaan itsetarkoitus ja välinekokonaisuus tulee olla hallittavissa maatilalla.

Oleellista kehitysprosessissa oli syventää aihepiiriin liittyvää tietoa case- maatilojen avulla. Menetelminä olivat asiantuntijaworkshopit, maatilayrittäjien case- haastattelut, tilastotutkimus ja lomaketestaukset. Turun Aikuiskoulutuskeskus järjesti hankkeeseen liittyen pilottikoulutuksen, jossa workshopit järjestettiin maatilayrittäjien kanssa. Koulutusohjelmaan osallistui aktiivisesti 8 maatilayrittäjää Lounais- ja Etelä-Suomesta. Maatilojen tuotantosuuntia olivat kasvintuotanto, naudanlihantuotanto, erikoiskasvituotanto, avomaavihannestuotanto ja maidontuotanto. Maatilojen hehtaaripinta-alat tai eläinyksikkökoko eivät olleet mitenkään poikkeuksellisen suuria, vaan paremminkin tilat olivat lisäarvoa tuotteilleen panostavia keskikokoisia tai pieniä tiloja, joita kiinnosti 
oman maatilan turvallisuus ja maatilan kehittäminen. Tiloista valittiin koulutusohjelman jälkeen kaksi kasvin- ja kolme eläintuotantotilaa testaamaan välineitä. Lisäksi hankkeessa tehtiin kysely 1499 maatilan turvallisuusasioista ja tilojen kokemista riskeistä Leppälä ym. 2006). Kyselyn vastauksia analysoitiin muodostamaan yleiskuva maatilojen riskeistä ja sitä käsitellään erillisessä artikkelissa.

\section{Tulokset}

Maatila-RH -välineperhe koostuu maatilan laaja-alaisesta riskikartasta ja siihen liittyvistä neljästä tarkistuslistasta ja analysointivälineestä. Välineperhe on lähtökohtaisesti tarkoitettu viljelijöiden omaan käyttöön, mutta se soveltuu myös alan asiantuntijoiden ja neuvontajärjestöjen käyttöön. Välineperheen uutuusarvo on siinä, että ensimmäistä kertaa on koottu yhteen kaikki maatilojen riskilajit sellaisen työkalun muotoon, jota voidaan käyttää erityyppisillä maatiloilla johtamisen apuna. Riskikartan tarkoituksena auttaa muodostamaan yleiskuva maatilan riskikentästä. Osa-alueittain koottujen avainsanojen avulla luodaan mielleyhtymiä ja ideoita maatilan toimintoihin liittyvistä mahdollisista uhkatekijöistä, jotka voivat aiheuttaa riskejä, vaikuttaa riskeihin tai joihin liittyy riskejä. Tilan kannalta merkityksettömiä tekijöitä ei käsitellä.

Maatilan johtamisen moninaisuutta ja erityisyyttä on käsitelty paljon aikaisemmissa tutkimuksissa. On tiedettävä, mitkä asiat vaikuttavat maatilan toimintaan ja mitä tehtäviä on maatilayrittäjän vastuulla (2005; Haapanen ym. 2004; Pietola 2003; Sonkkila 2002; Öhlmer ym. 2000). Näitä maatilan eri osa-alueita ja tehtäviä koskevista riskeistä muodostettiin maatilan riskikartta (kuva 1).

\section{Maatilan riskikartta}

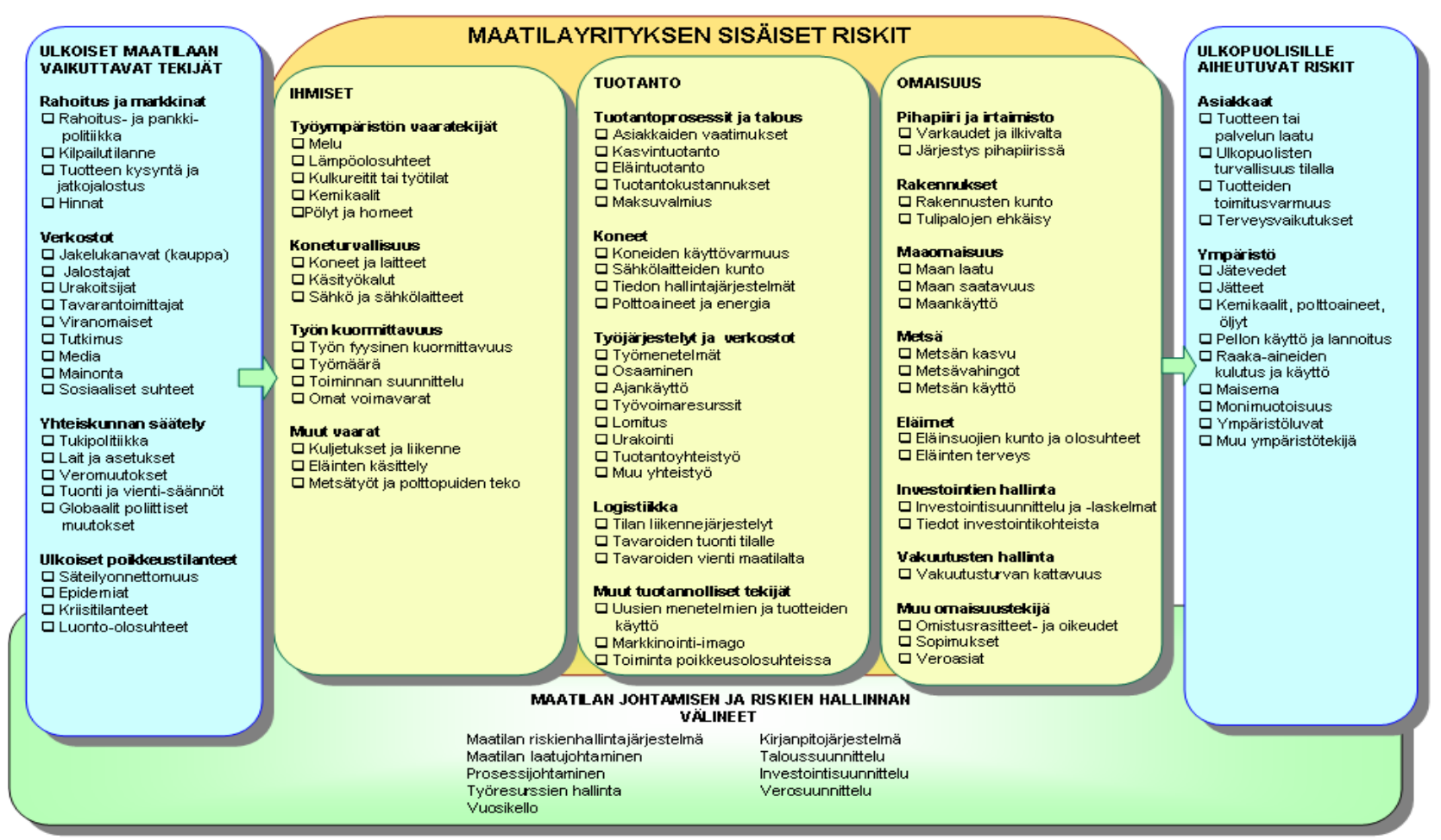

Kuva 1. Maatilan riskikartta (Murtonen, Leppälä, Mäkelä \& Suutarinen). Maatilaan ja sen toimintaan liittyvien riskien käsittelyä helpottaa niiden jäsentäminen riskikohteiden mukaisiin osa-alueisiin. Maatilan riskikartta luonnosteltiin asiantuntijaworkshopissa hankkeen aluksi.

Riskikartta kehittyi hankkeen aikana, kun osa-alueisiin syvennettiin osa-alueisiin liittyviä kysymyksiä. Riskikartan vasemmalla sivulla on maatilaan ja sen riskeihin vaikuttavat ulkopuoliset tekijät. Keskellä riskikarttaa ovat maatilan sisäiset merkittäviä riskejä sisältävät osa-alueet, joihin maatila voi itse vaikuttaa. Riskien kohteena on maatilan työturvallisuudessa ihmisten terveys, tuotantoriskeissä tuotannon jatkuvuus ja arvo, omaisuusriskeissä omaisuuden arvo ja ympäristöriskeissä ympäristöarvot. Riskilistojen kysymyksissä on huomioitu kohteiden kannalta merkittäviä seurauksia ja mahdollisuutta tapahtua. Oikealla puolella kuviota ovat maatilalta ulos siirtyvät riskit. Kuvion alaosassa on käytäntöjä, joilla maatilan riskien kokonaisuutta voi johtaa. 
Maatilojen käyttämistä riskien hallinnan välineistä suurin osa on kuitenkin ns. perinteisiä keinoja kuten tavallista vero- tai kustannuskirjanpitoa, investointisuunnittelua jne., joissa riskien käsittely on kuitenkin usein hyvin rajattua ja tiedostamatonta.

\section{Välineiden testaaminen}

Tilahaastatteluissa testattiin riskilistojen kysymyksiä työturvallisuus-, tuotanto-, omaisuus- ja ympäristöriskeistä. Tärkeää oli löytää kysymyksille sopiva tarkkuus, joka soveltuu maatilan itsearviointiin. Liian yleiset kysymykset koettiin turhauttavina ja toisaalta liian yksityiskohtaiset kysymykset menivät helposti liian vaikeiksi tai huonosti soveltuviksi tarkastellun maatilan olosuhteisiin. Kysymysten tason tulee olla sovellettavissa eri tilatyyppien tarpeisiin kuitenkin niin, että ne pysyvät ymmärrettävinä ja kysymyksiin liittyvä riski tai ongelma on nähtävissä.

Esim.

1. Ovatko ajettavien työkoneiden hallintalaitteet kunnossa?

2. Onko ajettavien työkoneiden hallintalaitteissa ollut vikoja?

Testausvaiheessa kysymysten erityyppisellä asettelulla nähtiin kummin päin vastaajat pystyvät paremmin hahmottamaan kysymykset. Positiivinen asetelma todettiin hyväksi (esimerkkikysymys 1). Jos kysymyssarjoissa on sekaisin eri tavoin aseteltuja kysymyksiä, kysymysten yhteenveto ja kokonaishallinta vaikeutuu koko riskienhallintasysteemissä. Kyllä -vastauksen tarkoitus eroaa näissä kysymyksissä toisistaan. Tämä ongelma poistuu, jos apuna on tietojärjestelmä, joka osaa automaattisesti lukea kysymyksen positiivisuuden tai negatiivisuuden oikein päin. Kaiken kaikkiaan jo alustavien karkeatasoisten riskilistojen avulla maatilat pystyivät löytämään maatilan toiminnalle merkittäviä riskejä, jotka useimmat olivat pienin parannuksin poistettavissa tai vähennettävissä (taulukot 2 ja 3). Maatilayrittäjä saattaa assosioida omaan toimintaansa liittyvän riskin pelkästä sanasta tai asiayhteydestä, mutta vastaajalle helpompi on kirjoittaa kysymys kokonaiseksi lauseeksi, josta seurauksen merkitys omalle tilalle on helpompi arvioida.

Riskilistoissa oli testausvaiheessa 114-250 kysymystä/lista. Kysymyksiin vastaaminen oli nopeaa siten, että kuhunkin osa-alueeseen liittyvä riskikartoitus oli ensimmäisellä täyttökerralla valmis noin 20-35 - minuutissa. Maatilayrittäjät tiesivät ja tunsivat hyvin etukäteen maatilansa resurssit ja tuotantoprosessit, mikä nopeutti ja helpotti riskien tunnistamista. On huomattava, että haastatellut tilat olivat käyneet hankkeeseen liittyvän koulutusohjelman. Aikaa kului enemmän, jos yrittäjä halusi pohtia tarkemmin riskien merkitystä ja seurauksia omalla tilalla ja mahdollisia toimenpiteitä riskin pienentämiseksi. Lisäksi riskien seurausvaikutusten ja kytkentöjen pohtiminen eri toimintojen välillä vei enemmän aikaa. Periaatteessa riskilistojen avulla maatilan riskien nykytilakartoitus on nopea tehdä.

Taulukko 2. Kasvintuotantotilojen riskienarviointia.

\begin{tabular}{|c|c|c|c|}
\hline Riskilaji & Riskin määritys & $\begin{array}{l}\text { Arvioitu } \\
\text { vakavuus }\end{array}$ & $\begin{array}{l}\text { Toimenpiteen } \\
\text { tarve }\end{array}$ \\
\hline Ympäristö & $\begin{array}{l}\text { Ei ole tarkistettu } \\
\text { kemikaalien ympäristöystävällisyyttä }\end{array}$ & Vähäinen & Pientä parantamista \\
\hline Omaisuus & $\begin{array}{l}\text { Ei tietoa toiminnasta hätätilanteissa, } \\
\text { palotarkastuksia ei ole tehty }\end{array}$ & Kohtalainen & Pientä parantamista \\
\hline Omaisuus & $\begin{array}{l}\text { Myrskytuhoihin varautuminen ja } \\
\text { eläinten aiheuttamiin vahinkoihin } \\
\text { varautuminen puutteellista }\end{array}$ & Kohtalainen & Pientä parantamista \\
\hline Tuotanto & Sähköhäiriöt ja varajärjestelmien puute & - & - \\
\hline Tuotanto & Lomitusjärjestelyt & Kohtalainen & Pientä parantamista \\
\hline Työturvallisuus & $\begin{array}{l}\text { Työskentely pölyisissä tiloissa ja } \\
\text { homevaurioiden tarkastus }\end{array}$ & Kohtalainen & Pientä parantamista \\
\hline Työturvallisuus & $\begin{array}{l}\text { Liika työmäärä kiireaikoina, } \\
\text { henkilönsuojainten käyttö puutteellista, } \\
\text { ajokoneiden istuinten tärinä }\end{array}$ & - & - \\
\hline
\end{tabular}

Taulukko 3. Eläintuotantotilojen riskienarviointia. 


\begin{tabular}{|l|l|l|l|}
\hline Riskilaji & Riskin määritys & $\begin{array}{l}\text { Arvioitu } \\
\text { vakavuus }\end{array}$ & $\begin{array}{l}\text { Toimenpiteen } \\
\text { tarve }\end{array}$ \\
\hline Ympäristö & $\begin{array}{l}\text { Jäteveden puhdistuksessa } \\
\text { puutteita }\end{array}$ & Vähäinen \\
Omaisuus & $\begin{array}{l}\text { Toimintaa hätätilanteissa ei ole } \\
\text { mietitty, pelastussuunnitelman teko }\end{array}$ & Kohtalainen & $\begin{array}{l}\text { Välittömiä } \\
\text { toimenpiteitä tarvitaan }\end{array}$ \\
\hline Omaisuus & Sähkölaitteiden kunto puutteellinen & Kohtalainen & $\begin{array}{l}\text { Välittömiä } \\
\text { toimenpiteitä tarvitaan }\end{array}$ \\
\hline Tuotanto & $\begin{array}{l}\text { Säilörehun laatuongelmat, } \\
\text { Ruokintasuunnitelmien teko }\end{array}$ & - & - \\
\hline Tuotanto & Lomitusjärjestelyt puutteellisia & Vakava & $\begin{array}{l}\text { Välittömiä } \\
\text { toimenpiteitä tarvitaan }\end{array}$ \\
\hline Tuotanto & $\begin{array}{l}\text { Lannankäsittelyjärjestelmät } \\
\text { puutteellisia }\end{array}$ & Kohtalainen & $\begin{array}{l}\text { Välittömiä } \\
\text { toimenpiteitä tarvitaan }\end{array}$ \\
\hline Työturvallisuus & Liiallinen työmäärä viikoittain & Vakava & $\begin{array}{l}\text { Välittömiä } \\
\text { toimenpiteitä tarvitaan }\end{array}$ \\
\hline Työturvallisuus & Eläinpölylle altistuminen & Vähäinen & Pientä parantamista \\
\hline
\end{tabular}

\section{Muut riskienhallinnan välineet}

Maatilan riskikartta ja riskilistat eivät olleet ainoita kehiteltyjä riskien hallinnan välineitä hankkeessa. Hankkeessa ei ollut riittävästi aikaa testata yhtä paljon kaikkia riskivälineitä, joista osa jäi nyt Maatila RH- välineperheen ulkopuolelle. Muita välineitä olivat maatilan prosessikartoitustyökalut, vuosikello, resurssikartoitus ja yhteenvetolomakkeet, joita voi kehittää jatkossa. Hankkeessa mukana olleet tilat pisteyttivät riskienhallinnan välinepaketissa olleita välineitä jaetulla kysymyslomakkeella (kuva 2).

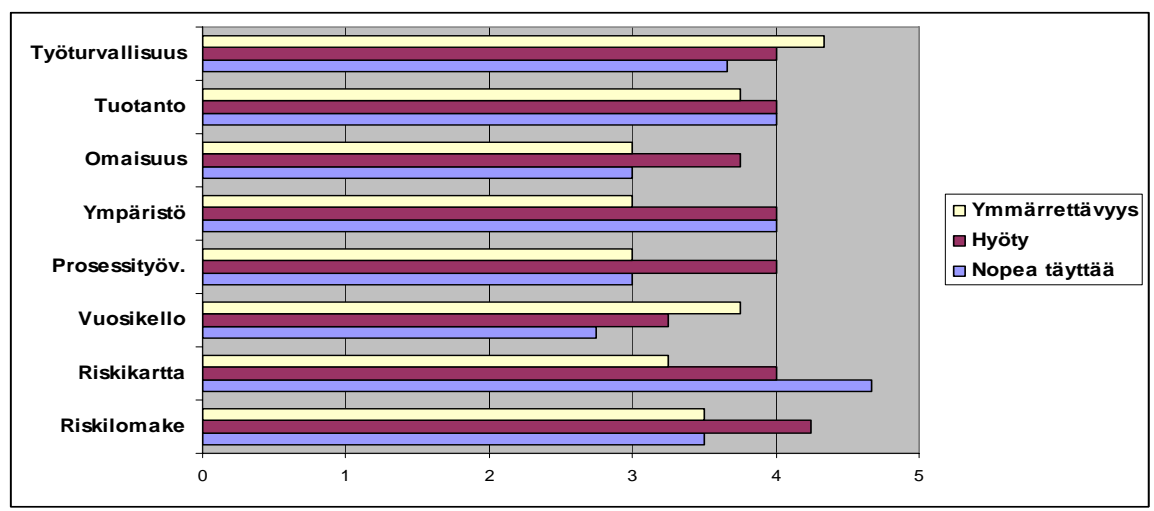

Kuva 2. Riskivälineiden palautearviointia case- maatiloilta ( 5 = samaa mieltä, $1=$ eri mieltä).

\section{Johtopäätökset}

Maatilan prosessien ja resurssien nykytila tulisi tiedostaa, jotta maatilayrittäjä voi paremmin arvioida tilan toimintaan ja muutoksiin liittyviä riskejä. Maatalouden muutos Suomessa aiheuttaa sen, että maatilojen on oltava entistä paremmin tietoisia tuotantonsa riskeistä ja turvallisuudesta. Merkittäväksi tämän kehityksen tekee viimekädessä se, mikä sen vaikutus on maatalouden työtapoihin, konekapasiteetin kasvuun, toiminnan riskeihin ja turvallisuuteen sekä johtamiseen. Jos tuntee riskinsä, niin voi lähteä sitä kautta selvittämään myös tuotantonsa vahvuuksia, heikkouksia ja mahdollisuuksia.

Riskin suuruuden toinen peruselementti, haitallisten tapahtumien todennäköisyys koettiin toisinaan hankalaksi määrittää maatilayritysten toiminnassa. Kehittämisprosessin aikana pohdittiin riskin numeerisen suuruuden määrittämisen tarvetta maatiloilla. Usein onkin riittävää pohtia suoraan riskin merkittävyyttä laadullisella tasolla. Käytännössä tämä tarkoittaa päätöstä siitä, onko riski niin merkittävä, että sen pienentämiseksi tulee toteuttaa toimenpiteitä. Tällöin riskienhallintaprosessin vaiheista korostuvat riskin tunnistaminen ja päätökset toimenpiteistä riskien pienentämiseksi. Nämä ovat toisaalta juuri keskeiset riskeihin liittyvän päätöksenteon vaiheet. Riskien kartoitus tehdään edeten yleisestä tarkastelusta yhä yksityiskohtaisempaan tarkasteluun, mitä yrittäjä pitää kussakin tilanteessa tarkoituksenmukaisena.

Kokonaisvaltaisissa maatilan johtamisen hallintavälineissä tulisi olla myös konkreettisia keinoja pienentää riskejä, kohdentaa ja rajata asioita kokonaiskuvan hahmottamisen jälkeen sekä sisältää välineitä yhteenvetojen tekoon. Riskienhallinnan keinoja tulisi maatiloilla tarkastella jatkossa 
tarkemmin, nyt kun riskien tunnistamisen välineet ovat olemassa. Muuten tarkastelu jää helposti tiloilla liian yleiseksi ja pahimmassa tapauksessa hyödyttömäksi. Maatiloilla hyvän johtamisen tulee viimekädessä näkyä toiminnassa ja tuotannossa parantuneina tuloksina.

Kiinnostavaa tietysti on, voidaanko maatilojen riskejä yhteismitallistaa tilojen turvallisuusvertailua varten. Täysin samanlaisia maatiloja tuskin on, mutta on maatiloja, jotka toteuttavat samantyyppisiä työvaiheita ja heillä on samantyyppisiä rakenteita ja koneita käytössä. Tällöin voidaan olettaa, että toiminnan riskejä tai laatua voidaan mitata tietyillä kysymyksillä, mutta asia vaatii jatkotutkimusta.

Uudet riskienhallinnan välineet on tarkoitettu maatilan johtamisen tueksi ja niiden avulla voi mahdollisesti vähentää tuotantoprosessien häiriöitä sekä parantaa tuotanto-olosuhteita, mutta tätä tulisi seurata välineitä käyttävillä maatiloilla jatkohankkeessa. Mutta jo sekin olisi arvokasta maatilojen riskien hallinnan kannalta, että tiloilla pysähdytään edes hetkeksi miettimään, mitkä eri tekijät voivat vaarantaa turvallisuutta tilalla tai miten tilan tavoitteiden toteutuminen mahdollisesti on uhattuna. Tämä pohdinta ja keskustelu ei maksa kuin aikaa muutaman tunnin. Maatilan riskien hallinta voi toimia myös osana laadun hallintaa, sillä se on erilaisten johtamisperiaatteiden ja hallintakeinojen järjestelmällistä käyttämistä maatilaa uhkaavien riskien tunnistamiseksi, niiden merkityksen arvioimiseksi, toimenpiteiden toteuttamiseksi ja valvomiseksi. Laadukkaassa toiminnassa riskit ovat hallinnassa ja häiriöitä on vähän.

\section{Kirjallisuus}

Boehlje, M. 1999. Structural Changes in the Agricultural Industries: How Do We Measure, Analyze and Understand Them? American Journal of Agricultural Economics, Vol. 81, No. 5, Proceedings Issue (Dec., 1999), pp. 1028-1041.

Carnaghan, C. 2006. Business process modelling approach in the context of process level audit risk assessment: An analysis and comparison. International Journal of Accounting Information Systems 7. (2006) ss. 170-204.

COSO. 2004. Enterprise risk management - Integrated framework. Executive summary. Committee of sponsoring Organizations of the Treadway Commission. $7 \mathrm{~s}$.

Hardaker, J. Brian, Huirne, Ruud B.M., Anderson, Jock R. \& Gudbrand Lien 2004. Coping with risk in Agriculture. Second edition.

Haapanen, M. Heikura, J. Leino, K. 2004. Maatila liikeyrityksenä. WSOY. Helsinki.

Jokipii, P. \& Leppälä, J. 2005. Maatilan johtaminen ja riskienhallinta : mitä johtaminen on? : riskien hallinta osana johtamista: Julkaisussa: Maatilan riskienhallinta. Tieto tuottamaan 110:, 4-22, MKL:n julkaisuja.

Karhu, R. 2005. Maatilojen turvallisuushanke. Loppuraportti. Etelä-Pohjanmaan pelastuslaitos. Seinäjoki.

Lanne, M. 2007. Yhteistyö yritysturvallisuuden hallinnassa. Tutkimus sisäisen yhteistyön tarpeesta ja roolista suurten organisaatioiden turvallisuustoiminnassa. VTT Publications 632. VTT, Espoo. $118 \mathrm{s.}$

Leppälä, J., Suutarinen, J., Murtonen, M. 2006. Risk perception among Finnish farmers : survey of farm risk management. NJF seminar 375 on Farm Risk Management. Norway.

Levä, 2003. Turvallisuusjärjestelmien toimivuus: vahvuudet ja kehityshaasteet suuronnettomuusvaarallisissa laitoksissa. TUKES-julkaisu 1/2003. TUKES, Helsinki. 163 s.

Pietola, K. 2003. Laajentamisen riskien hallinta. Julkaisussa: Enroth, A., Österman, P. \& Teräväinen, H. Laajentavien tilojen haasteet. Tieto tuottamaan 104. MKL:n julkaisuja.

SFS-EN ISO 13407.1999. Vuorovaikutteisten järjestelmien käyttäjäkeskeinen suunnitteluprosessi. Suomen standardisoimisliitto. Helsinki.

SFS-IEC 60300-3-9. 2000 Luotettavuusjohtaminen. Osa 3: Käyttöopas. Luku 9: Teknisten järjestelmien riskianalyysi. Suomen Standardisoimisliitto, Helsinki. $47 \mathrm{~s}$.

SFS OHSAS 18001.2000. Työterveys- ja työturvallisuusjohtamisjärjestelmät. Spesifikaatio. Suomen

Standardisoimisliitto. Helsinki.

Simola, A. 2005. Turvallisuuden johtaminen esimiestyönä, Väitöskirja. Oulun yliopisto.

Sonkkila, S. 2002. Farmer's decision making on adjustment into the EU. Helsinki University, Department of Economics and Management. Publications 34. Academic dissertion. Finland. Helsinki University. p.160.

Suutarinen, J. 2003. Occupational Accidents in Finnish Agriculture - Causality and Managerial Aspects for Prevention. Doctoral Dissertion. MTT. Vakola.

Reason, J. 1995. A systems approach to organizational error. Ergonomics, 1995, vol 38, no.8, 1709-1721. Rikkonen, P. 2005. Utilisation of alternative scenario approaches in defining the policy agenda for future agriculture in Finland. Agrifood Research Reports 73: Doctoral Dissertation. 223 s.

Öhlmer, B., Göransson, B., Lunneryd, D. 2000. Business Management - with Applications to Farms and Other Businesses. Sveriges lantbruksuniversitet Institutionen för ekonomi. Uppsala. Ruotsi. 248 s. 